\section{Tendensiøst om stråling}

Kraus W.

Mobilstråling

160 s, tab, ill. Oslo: Spartacus, 2009.

Pris NOK 199

ISBN 978-82-430-0469-6

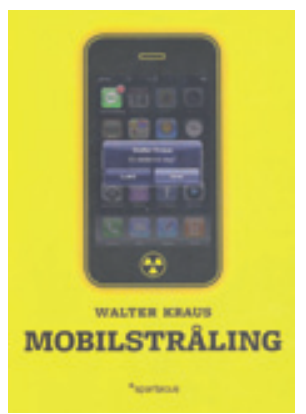

Forfatteren henvender seg til de brede lag av befolkningen med noe som kan anses som et partsinnlegg for å få satt ned eksisterende grenseverdier for mobilstråling og elektromagnetiske felter. Han forsøker å gi inntrykk av at han har gjennomgått eksisterende forskning på området for å begrunne sitt ståsted og kommer innimellom med eksempler fra sitt virke innen alternativmedisinen. For leger i allmennpraksis vil kjennskap til forfatterens argumentasjon være nyttig, og jeg vil her komme med noen vurderinger som de bør kjenne til når mobilstråling og eloverfølsomhet diskuteres.

Det er seks hovedkapitler, 12 tabeller, åtte enkle figurer og et forord av Olle Johansson i tillegg til 107 referanser, herav ca. 12 til vitenskapelige artikler. De øvrige er først og fremst nettadresser av ymse slag. Referanselisten er ordnet etter innfallsmetoden. Dette burde forlaget ha ordnet opp i.

Walter Kraus driver en virksomhet på Sørlandet der han forsøker å helbrede syke ved å endre deres eksponering for vannårer. I tillegg driver han med «elsanering» for folk som karakteriseres som eloverfølsomme. Han har ingen forskerutdanning eller -erfaring, men er en representant for alternativmedisinen $\mathrm{i}$ en viss forstand.

Jeg har valgt å trekke frem noen hovedtrekk ved hans fremstilling og illustrere disse med noen detaljer.

\section{Gjennomgang av eksisterende forskning}

Kraus refererer til forskning for å begrunne at man bør ha lavere grenseverdier for mobilstråling enn de som gjelder i dag. Spesielt i kapitlet om mobilstråling og helse, det desidert største (55 sider), kommer hans manglende forskningserfaring til syne. Han trekker frem enkeltundersøkelser og bruker formuleringer som «det eksisterer meget tydelige bevis for» om både det ene og det andre, uten direkte henvisning til kilden. De undersøkelsene som ikke passer med hans oppfatninger, nevnes bare i form av en sekkepost et par-tre steder og bagatelliseres ved formuleringer som «Det finnes en rekke motstridende forskningsresultater. Disse kan føres tilbake til det faktum at det ikke finnes kontrollgrupper som ikke er eksponert». Dette er et ganske utrolig utsagn som svekker forfatterens troverdighet.

Jeg har selv 18 års forskningserfaring innen helseeffekter og biologiske effekter av elektromagnetiske felter. Mange publiserte resultater har ikke latt seg bekrefte i replikasjonsforsøk. Det er flere viktige grunner til dette. Fagfeltet er komplisert fordi det krever grundig kunnskap innen vidt forskjellige disipliner, som fysikk, biologi/medisin og til dels statistikk/epidemiologi. I mange tilfeller er arbeider gjennomført uten tilstrekkelig kompetanse innen en av disse disiplinene, og følgen er faglige bommerter og mistolking av resultater. Videre er det vanligvis snakk om meget svak (eller ingen) biologisk/medisinsk virkning ved eksponering for elektromagnetiske felter i frekvensområdene/intensiteten folk flest utsettes for. Følgelig viser noen undersøkelser statistisk signifikante effekter, mens andre ikke gjør det. Av begge grunner må man være spesielt edruelig når man trekker slutninger, og ikke la seg friste til kun å velge ut eksempler der det er vist effekt. Kraus overbeviser ikke i gjennomgangen av forskningsresultatene. Han henter frem enkeltundersøkelser og opphøyer disse til «sannheter». Det blir ganske meningsløst.

Han viser stadig til den såkalte Bioinitiativ-rapporten, som kom i 2007. Den omhandler biologisk effekt av elektromagnetiske felter og er skrevet av forskere og folk fra ulike pressgrupper. Dette er ingen objektiv gjennomgang av forskningen på området - det er de mest radikale på «farefare-siden» som står bak, de som hører til på «ingen-fare-siden» er ikke med. Noen forskere som befinner seg mellom disse ytterlighetene har bidratt med deler av rapporten, men stiller seg ikke bak andre deler av den. Kraus ser ikke dette poenget, for han omtaler rapporten som «Den mest pålitelige og aktuelle oppsummeringen av internasjonal forskning» på området. Man kan undres på om han overhodet har lest artikler som kommer fra motsatt fløy, f.eks. artikler samlet i Biological effects of lowfrequency electromagnetic fields (1).

\section{Eloverfølsomhet}

Kraus synes å mene at det er samme type problemer med mobilstråling som med lavfrekvente elektromagnetiske felter fra f.eks. kraftledninger og elektriske installasjoner. Et av problemene er såkalt eloverfølsomhet, og det er ganske interessant å se hvilke oppfatninger han har om dette.

Når han omtaler eloverfølsomme, synes han å ta for gitt at deres reaksjoner alltid er korrekte og at årsaken alltid er det elektromagnetiske feltet. Er feltet svært lite, ja så er det bare et tegn på at personen er tilsvarende følsom. Han henviser til at enkelte kan kjenne felter som er mindre enn milliondelen av eksisterende grenseverdier, og kommer ikke med noen motforestillinger mot en slik oppfatning. Folk flest tror kanskje det ikke finnes noen nedre grense for hvilke felter man kan påvirkes av, men forskningen gir ingen støtte for et slikt syn.

Jeg har selv hatt med flere eloverfølsomme å gjøre i min egen forskning, og har stadig opplevd at det er klar inkonsistens i deres reaksjonsmønstre. Selv trodde jeg $i$ over ti år at jeg kunne kjenne magnetfelter over en viss grense - betydelig høyere enn grenseverdien, men mindre enn feltverdier hvor det er rapportert sikre effekter. Jeg kjente feltene hver gang jeg stakk underarmen inn i et spesielt magnetfelt i laboratoriet. Da jeg ønsket å dokumentere mitt funn, gjorde jeg et dobbeltblindt eksperiment. Resultatet ble en ordentlig nedtur: Jeg klarte ikke å kjenne feltene under dobbeltblindbetingelser, jeg kjente dem bare når jeg visste om de var på eller av. Jeg hadde altså lurt meg selv i over ti år og var selv blitt offer for placeboeffekten! Det er gjort mange dobbeltblindforsøk med eloverfølsomme, og som regel kan man ikke påvise noen reaksjon under slike forhold. Da er det ganske utrolig å lese Kraus' ureflekterte tro på alle eloverfølsomhetsreaksjoner.

Han har i en årrekke «hjulpet» eloverfølsomme, og ifølge denne utgivelsen har det særlig foregått gjennom elsanering, dvs. at man forsøker å redusere feltene ved hjelp av skjerming eller ved å få folk til å flytte vekk fra kildene. Jeg undres på hvor mange eloverfølsomme han har anbefalt å flytte til en hytte i skogen, langt fra folk. Håper det ikke er mange!

Det er bemerkelsesverdig at Kraus ikke nevner andre forsøk på å hjelpe eloverføl- 
somme. Selv er jeg fascinert av arbeidet som bl.a. Lena Hillert har gjort i Sverige, der de har en kommisjon som hjelper eloverfølsomme. Den består av en tverrfaglig gruppe, der bl.a. fysiker, lege, psykolog, sosionom og fysioterapeut inngår. Fysikeren måler felter og foreslår elsanering om det synes å være aktuelt. Hillert fortalte $\mathrm{i}$ et foredrag for noen år siden at det sjelden blir gjort elsanering, fordi reduksjon av de elektromagnetiske feltene hadde begrenset virkning. Andre faktorer var viktigere. Denne type opplysninger gir ikke Kraus. Hans sterke kritikk av myndigheter og alle som ikke er av samme oppfatning som han selv kan vanskelig tas alvorlig.

\section{Myndighetenes håndtering av mobilstråling}

Dagens anbefalte grenseverdier for mobilstråling og elektromagnetiske felter er basert på helt sikre effekter, nemlig ufrivillig trigging av nerver ved lavfrekvente felter og oppvarming ved høyfrekvente. Foreløpig har man ikke funnet sterke nok bevis for andre skadelige effekter til å ta hensyn til disse i de offisielle grenseverdiene. Dette er selvfølgelig en beslutning som kan diskuteres.

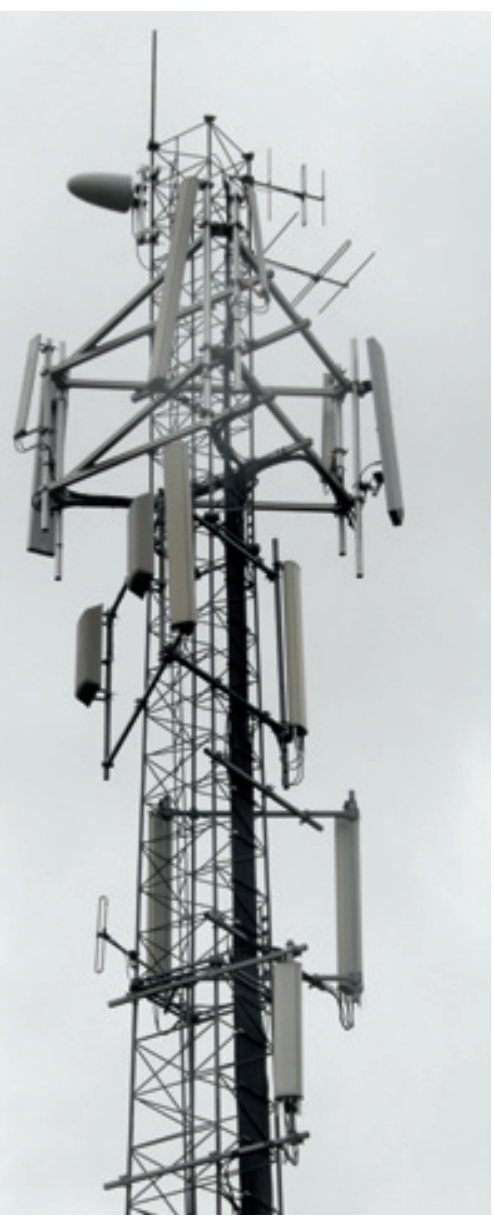

Basestasjoner for mobiltelefoni sender ut mikrobølger, men med svært mye lavere intensitet enn det vi finner inne i en mikrobølgeovn. Er denne formen for «stråling» farlig? WHO og andre har hittil ikke klart å konkludere. Foto Arnt Inge Vistnes
Kraus mener at ethvert forskningsresultat som kan tyde på en biologisk effekt (isolert sett) må tas alvorlig. Videre mener han at de eloverfølsommes reaksjoner skyldes elektromagnetiske felter, uansett hvor lave de er. Når det er utgangspunktet, er det naturlig at han arbeider for å få lavere grenseverdier. Han mener at hans oppfatninger, og oppfatningene i Bioinitiativ-rapporten, må danne grunnlag for regelverket i samfunnet, og stiller spørsmålet om hvem som faktisk skal ha tolkingsautoritet når det gjelder biologiske effekter av f.eks. mobilstråling. Han mener at man i Statens strålevern er uansvarlige.

Hittil har Statens strålevern, og tilsvarende organer i de fleste land, basert sin forvaltning på vurderinger fra Verdens helseorganisasjon (WHO) og International Commision on Non-Ionizing Radiation Protection (ICNIRP). I disse organene har vitenskapelige komiteer forsøkt å vurdere all forskning, ikke bare et utplukk, slik Kraus gjør. I tillegg avveies nytte og risiko. Kraus viser i begynnelsen av boken til at mobiltelefonen er nyttig, men nytteaspektet synes å forsvinne helt etter hvert. Når han mener at man bør ta høyde for de mest ekstreme forskningsresultatene i grenseverdisettingen, blir det hele ganske virkelighetsfjernt. Skulle man brukt samme argument på andre risikoer i samfunnet, burde man forby bilkjøring, fordi biltrafikk representerer en risiko for død, også for dem som ikke har bil. For biltrafikken er dessuten risikoen dokumentert på en helt annen måte enn for mobilstrålingen.

Ikke $\mathrm{i}$ alle land følger anbefalinger fra WHO og ICNIRP, og Kraus forsøker å gi inntrykk av at man andre steder har en mer ansvarlig politikk enn hos oss. Iveren blir litt for stor innimellom. I en tabell sier han at et EU-direktiv angir en grenseverdi på 2,4 mikrowatt per $\mathrm{cm}^{2}$ (s. 63-4). Dette direktivet gjelder imidlertid elektromagnetisk kompatibilitet (EMC), dvs. krav som stilles til elektronisk utstyr for at én utstyrsenhet ikke skal forstyrre en annen. Dette har ikke noe med grenseverdier for eksponering hos mennesker å gjøre og hører ikke hjemme i tabellen som er gitt.

Kraus fremhever at man i et område i Østerrike har vedtatt lavere grenseverdier enn i de fleste andre land, og han hevder at det kan gjøres uten problemer fordi alt kommunikasjonsutstyr kan drives like godt med lavere effekt enn i dag. Den påstanden betviler jeg sterkt. Vi opplever alle iblant ikke å få kontakt med basestasjoner ved dagens nivå. Hvordan kan man da hevde at selv hundreparten av effekten vil fungere like bra som dagens? Jeg reagerer også på den uforbeholdne mistenkeliggjøringen av industrien. Kraus synes å ha oversett at det er i alles interesse å få strålingen så lav som mulig, også for industrien. Kunne vi klart oss med lavere stråling, ville f.eks. batteriladningen holde lenger. Den mobiltelefon- fabrikanten som lager et produkt som klarer seg med mindre effekt enn dagens og ellers like god yteevne, vil ha et konkurransefortrinn.

På et par områder har Kraus gode poenger. For det første er det nærmest en farsott i dag at alt skal være trådløst. Selv om jeg personlig har lite tro på skadelige effekter av stråling fra trådløse telefoner, lokalnett osv., så er forskningsresultatene ikke entydige. Det kan derfor være greit å tenke seg om to ganger før man plasserer slikt utstyr - og trengs det egentlig i enhver sammenheng?

For det andre kritiserer han informasjonen fra Statens strålevern. Strålevernet sier at det ikke er fare ved f.eks. mobiltelefonstråling - likevel anbefaler de bruk av handsfree og at man bør være forsiktig angående barns bruk av mobiltelefoner. Det er nok ikke bare Kraus som ikke helt forstår denne dobbeltkommunikasjonen. Strålevernet bør få frem at de samlede forskningsresultater per i dag gir såpass svake holdepunkter for at mobiltelefonstråling er farlig at de ikke har funnet det nødvendig å innføre skjerpede grenseverdier. Likevel, så lenge det er en viss usikkerhet, kan folk, dersom de ønsker det, redusere strålingen med enkle midler. Strålevernet kan så gi råd om hvordan dette kan gjøres. Denne problemstillingen bør vurderes nøye slik at folk flest lettere kan forstå tankegangen bak rådene som gis.

\section{Konklusjon}

Mobilstråling er for spesiell og for ensidig og har for mange feil til å være interessant. En mer balansert fremstilling av problemstillinger ved elektromagnetiske felter, mobilstråling og helse finnes på WHOs nettsider (2). Gjeldende grenseverdier og ICNIRPs anbefalinger og vurderinger finnes også på Internett $(3,4)$. Her listes det opp en del originalartikler som kan være av interesse og en fersk oversiktsartikkel som kan være nyttig for mange (5).

\section{Arnt Inge Vistnes}

Fysisk institutt

Universitetet i Oslo

\section{Litteratur}

1. Hafemeister D, red. Biological effects of low-frequency electromagnetic fields. College Park, MD: American Association of Physics Teachers, 1998.

2. World Health Organization. Electromagnetic fields. www.who.int/peh-emf/en/ (12.10.2009).

3. International EMF Project. EMF worldwide standards. www.who.int/docstore/peh-emf/ EMFStandards/who-0102/Worldmap5.htm (12.10.2009).

4. International Commission on Non-lonizing Radiation Protection. www.icnirp.org/PubEMF.htm (12.10.2009).

5. Ahlbom A, Feychting M, Green A et al. Epidemiologic evidence on mobile phones and tumor risk: a review. Epidemiology 2009: 20: 639-52. 